\title{
Free Movement of Judgments in Cross-Border Money Laundering Crimes: A Legal Stance toward the ASEAN Legal Integration
}

\author{
Efendi L. Simanjuntak ${ }^{*}$ Y Yuris T. Naili** \& FX Adji Samekto ${ }^{* * *}$
}

Transnational money laundering is a global issue that requires international solutions. This paper examines the concept of Free Movement of Judgments which should be realized in the legal integration process of the ASEAN in order to overcome the negative impacts of money laundering. This research will analyze the regulation for criminalizing money laundering in the ASEAN and compare it with the criminal cooperation in the European Union. The ASEAN Treaty on Mutual Legal Assistance in Criminal Matters (MLAT 2004) is expected to be an alternative to an extradition treaty. If adopting the Free Movement of Judgements, judicial decisions of an ASEAN member country regarding transnational crimes of money laundering would be recognized and implemented in other member's jurisdiction reciprocally. This adoption is expected to be an effective solution to overcome impunity in cross-border money laundering actors.

\section{Keywords}

Extradition, MLAT 2004, Money Laundering, ASEAN, Free Movement of Judgments, Integration of Law

* Doctoral student at Diponegoro University, Semarang, Indonesia. LL.B. (Bandung U.), LL.M. (U. Indonesia). ORCID: https:/orcid.org/0000-0002-0178-3591. This work was supported by the doctoral research program at Diponegoro University. The author may be contacted at: eldanalegal@gmail.com/Address: Tanjung Mas Raya Blok B/31 Tanjung Barat, South Jakarta, Indonesia. All the websites cited in this article were last visited on November 7, 2019.

** Doctoral students at Sultan Agung Islam University, Semarang; Lecturer of Law at Harapan Bangsa University, Purwokerto, Indonesia. ORCID: https://orcid.org/0000-0001-8809-7035. Address: Jl. Banteran Rt. 03 Rw. 04, Banteran, Sumbang, Banyumas, Jawa Tengah 53183, Indonesia.

*** Professor of Law at Diponegoro University, Semarang, Indonesia. ORCID: https://orcid.org/0000-0001-7013-933X. Address: Jl. Srondol Asri Blok J.9, Belakang Asrama Banteng Raiders Semarang, Jawa Tengah 50261, Indonesia. 


\section{Introduction}

Transnational crime is a real threat to peace and prosperity of today's international community. It used to damage the global economy. ${ }^{1}$ Transnational crime has been increasing mainly due to the development of information technology and the transportation in the borderless world. ${ }^{2}$ This causes the perpetrators to commit their crimes in various countries across jurisdictions.

Today, it is difficult to detect money laundering, mainly because moneys are washed or transferred across jurisdictions between countries in very large numbers. It has grave impact on many countries. ${ }^{3}$ Transnational money launderers can easily flee to foreign jurisdictions in order to avoid the pursuit of law enforcement officers in the country where the crime was committed. These international fugitives can give birth to impunity against the perpetrators who are free from the snares of the law. Those involved in cross-border money laundering have become a global issue that requires international solutions. As of today, cross-border money laundering has reached 5 percent of the world's gross domestic product, which is equivalent to USD 590 billion to USD 1.5 trillion per year. ${ }^{4}$ In another instance, Indonesia itself has faced 2,500 trillion rupiah of dirty money in the last 10 years. Actually, the crime proceeds from the Bank of Indonesia Liquidity Assistance ("BLBI") in the 1997-99 Asian monetary crisis was enormous. Indonesian fugitives in Singapore alone stored around 600 trillion rupiah. ${ }^{5}$ The problem of Indonesian fugitive assets which spread abroad, especially the results of crimes in the case of the BLBI in Singapore, is further complicated by the absence of an extradition treaty between Indonesia and Singapore. The fugitives often manipulate the absence of an extradition treaty between the two countries in order to avoid lawsuits in Indonesia. Indonesia has difficulties in confiscating corrupt assets because the perpetrators cannot be arrested and tried. How is it then possible to confiscate corrupt assets if the perpetrators cannot be tried and convicted?

Important is cooperation between countries to eradicate the transnational crime.

1 J. Hagedorn, The global impact of gangs, 21(2) J. Contemp. CRim. Justice 153-69 (2005).

2 C. Gibbs, E. McGarrell \& M. Axelrod, Transnational white-collar crime and risk: Lessons from the global trade in electronic waste, 9(3) Criminology \& Pub. Pol’y 543-60 (2010).

3 P. Lilley, Dirty Dealing: The Untold Truth about Global Money Laundering, International Crime and Terrorism 2 (2003).

4 FATF, What is Money Laundering?, available at https://www.fatf-gafi.org/faq/moneylaundering.

5 For details, see R. Rusmin, \& A. Brown, Regulatory context: Recent progress on key aspects of Indonesia's anti-money laundering regime: a narrative analysis, 15(3) J. MONEy LAUNDERING CONTROL 257-66 (2012). 
If the perpetrators cannot be arrested and tried, these crimes will be repeated by the perpetrators. Moreover, the negative impacts caused by transnational money laundering will be more corrosive with a wide impact on the global financial system and the world economy. There are common concerns between countries on this negative impact and each country is trying to carry out cross-border law enforcement, especially for transnational crime actors.

Cross-border law enforcement against perpetrators is generally implemented by extradition treaty. However, the extradition is not always effective because it does not guarantee the repatriation of fugitives to the requesting state. This can be seen from the fugitive case of Djoko S. Tjandra. Tjandra was involved in the Bank Bali case and was sentenced to two years' imprisonment with around IDR 567 billion's confiscation. However, he escaped to Port Moresby and reportedly received citizenship from the Papua New Guinea. He has not yet been extradited to Indonesia despite the extradition treaty between the two countries and the enactment of Law No. 6 of 2015 concerning the Extradition Agreement between the Republic of Indonesia and Papua New Guinea. Likewise, Hendra Rahardja, ${ }^{6}$ another Indonesian fugitive, could not be extradited by Australia to Indonesia until the end of his life despite the extradition treaty between the two countries and the enactment of Law No. 8 of 1994 concerning the Extradition Agreement between Indonesia and Australia.

Conversely, there are cases for a fugitive to be repatriated without extradition treaty from the requested to the requesting country. ${ }^{7}$ In M. Nasaruddin case, Columbia sent him to Indonesia even though the two countries did not have extradition treaty. The case of Lim Yong Nam is similar. ${ }^{8}$ He was extradited by Indonesia to the US even though the two countries do not have an extradition treaty, either. This fact raises doubts about the effectiveness of extradition treaty. In practice, the requested country can make optional refusals in an extradition agreement in consideration of one's citizenship, while it can be mandatory in other agreements.

6 He is suspected of committing a money laundering crime in Australia allegedly resulting from the criminal acts of corruption in Indonesia when he served as a shareholder and commissioner of Bank Harapan Sentosa (BHS). BHS was later liquidated by the Government of Indonesia in November 1997. This fugitive is reported to have died in Australia during the extradition process, so he was never extradited to Indonesia.

7 For example, the US and Cuba have an extradition treaty, but, because of hostile diplomatic relations between the two countries, hundreds of American perpetrators hiding in Cuba cannot be extradited. On the other hand, Spain is known to be very flexible with extradition requests. Despite the absence of an extradition treaty, Spain easily repatriated fugitives. See A. Handerson, The Best Non Extradition Countries to Become Invisible, Nomad CAPITALIST, Nov. 3, 2017, available at http://nomadcapitalist.com/2013/06/03/the-best-non-extradition-countries-to-be-invisible.

8 Lim Yong Nam is a fugitive from the US with Singaporean citizenship. In 2015, Riau Regional Police arrested and detained him on suspicion of smuggling a radio module. In 2015, he was extradited by Indonesia to the US based on State Secretariat Letter No.288/Setneg/03/15 dated March 20, 2015. 
The extradition process appears to be increasingly difficult and ineffective. ${ }^{9}$ The intergovernmental agreements on money laundering is important for state officials to expose money laundering from corruption easily. ${ }^{10}$ This reality also shows the anomalous, inconsistent, and contradictory situations of extradition treaty. Therefore, the Mutual Legal Assistance ("MLA") can be used as an alternative to extradition, especially without an extradition treaty between Indonesia and Singapore.

MLA was adopted based on a hypothesis that MLA and extradition instruments are co-existing as supplementary instruments of law enforcement. This means that without extradition instruments, MLA can function as an alternative instrument. Also, with extradition treaty, MLA would be a complement. The MLA instruments which exist as an alternative to extradition is getting more important and strategic in line with the signing of the 2004 ASEAN Treaty on Mutual Legal Assistance in Criminal Matters ("MLAT 2004") by all ASEAN member countries. ${ }^{11}$ A primary reason of MLAT 2004 is to localize and identify suspects in foreign jurisdictions. ${ }^{12}$

Even though all ASEAN countries have signed the 2004 MLAT, it is not yet effective enough (not very often used as an alternative) especially to Indonesian money laundering fugitives hiding in Singapore. This is because some law enforcers in Indonesia consider that MLAT 2004 cannot be used as an instrument against suspected individual. Therefore, it is necessary to think about how to build and develop the concept of "Free Movement of Judgments" in the criminal matters in order to try fugitives wherever they are in accordance with the principle of aut punire aut diere. ${ }^{13}$ The concept of "Free Movement of Judgments" is an essential idea of how the national court decisions of the ASEAN member countries in the criminal sector especially against cross-border money laundering can later be recognized and implemented in

9 R. Atmasasmita, Law on Extradition [Hukum Tentang Ekstradisi] 40 (2011).

10 Xiangqian Gong, International Joint Action against Corruption: Agreement between China and Canada regarding the Sharing of Forfeited Assets 6 J. EAST AsIA \& INT'L L. 594 (2013).

11 MLAT 2004 art. 2. It states that this MLAT does not apply/is not applicable to the arrest or detention of any person related to extradition, surrender of persons to carry out sentences, and transfer of proceedings in criminal matters. However, regarding the scope of the MLAT, Article 2(j) states that this MLAT includes "locating and identifying witnesses and suspect." See C. Le Nguyen, Towards the effective ASEAN mutual legal assistance in combating money laundering, 15(4) J. Money Laundering Control 383-95 (2012); S. Pushpanathan, Combating transnational crime, in 7th ACPF World Conference on Crime Prevention \& Crim. Just. Proc. 23-6 (1999).

12 Law No.1 of 2006 concerning Reciprocal Assistance in Criminal Matters, art. 3, ๆ 2. It states: "Assistance as mentioned in paragraph (1) may be in the form of a. Identifying and searching for people..."

13 J. Starke, Introduction to International Law (8th ed. 1989). For details on the application of free movement of judgment, see M. Hazelhorst, Free Movement of Civil Judgments in The European Union and the Right to A FaIR Trial (2017); M. Gal, Free Movement of Judgments: Increasing Deterrence of International Cartels through Jurisdictional Reliance. 51 VA. J. INT'L L. 57 (2010); C. Ambrose, Arbitration and the free movement of judgments 19 Arb. InT'L 3-26 (2003); S. Lane, Free Movement of Judgments within the EEC, 35 InT'L \& Comp. L. Q. 629-43 (1986). 
the national jurisdiction of other ASEAN member states. The "Free Movement of Judgments" would be adopted to prevent impunity by asylum-giving countries for trans-border money laundering actors and to arrest and try the perpetrators wherever they are. ${ }^{14}$ This paper will discuss how the "Free Movement of Judgements" has the potential to be realized in the ASEAN in an effort to avoid impunity for perpetrators regardless of the presence or absence of extradition treaty or MLA.

\section{Integration of Law in the ASEAN}

The negative impact of massive cross-border money laundering is fast increasing at this time. The ASEAN Declaration on Transnational Crime in Manila, 20 December 1997 addresses that money laundering is a global phenomenon and transnational crime. ${ }^{15}$ This shows that money laundering has given rise to a common concern among the ASEAN member countries which should be addressed collectively. It is difficult for one country to fully stop this transnational, cross-jurisdictional and organized crime without cooperation of other countries. Therefore, MLAT 2004 intended to carry out mutual assistance and cooperation in the criminal field concerning investigation, prosecution, and judicial process. The existence of MLAT 2004 can also be interpreted as a spirit of cooperation in the criminal field which can later become an embryo for legal integration in the ASEAN. ${ }^{16}$ It is expected in turn to support the sustainability of economic integration that has been running quite well in the ASEAN ${ }^{17}$ and to realize the cooperation between judicial bodies through the application of the concept of "Free Movement of Judgment" in the criminal field. Through cooperation between judicial bodies, judicial decisions in an ASEAN member country regarding money laundering crimes can be implemented in the jurisdiction of other countries reciprocally.

“The Free Movement of Judgments" was basically initiated by Tom Bingham

14 The universal jurisdiction is applied to transnational crimes based on humanitarian calls, especially those related to human rights cases.

15 ASEAN Declaration on Transnational Crime Manila, 20 December 1997, available at https://asean.org/?static post=asean-declaration-on-transnational-crime-manila-20-december-1997.

16 L. Thanadsillapakul, Legal and Institutional Frameworks for Open Regionalism in Asia: A Case Study of ASEAN, in East Asian Regionalism from a Legal Perspective: Current Features and a Vision for the Future 157-64 (T. Nakamura ed., 2009).

17 R. Intan, ASEAN's Relevance and Benefit: A Perspective from Indonesia, 43(3) InDon. Q. 7-20 (2015). 
as an international anti-criminal regime. ${ }^{18}$ Absence an extradition treaty between countries, money laundering victims cannot easily catch perpetrators seeking asylum in other countries. The "Free Movement of Judgments" here acts as a multilateral legal framework to limit and overcome cross-border crimes. Tom Bingham's theory of "enforcement jurisdiction" is attributed to Guys Stessens, with regard to the crossborder request relating to the court proceedings in the criminal cases. ${ }^{19}$ This means that each country is obliged to arrest transnational crime perpetrators wherever they are; if there is a formal request from the requesting country, the fugitives can be transferred to the country which wants to try the perpetrators. ${ }^{20}$

To realize law integration in the ASEAN through the "Free Movement of Judgments" is certainly not an easy task, given the different legal systems of the ASEAN member countries. For example, the civil law system adopted by Indonesia is not always consistent with the common law system adopted by Singapore in certain cases. The difference between the two legal systems give rise to the different interpretations of certain offenses which can have implications for the aspect of "dual criminality." It finally results in releasing the criminal offender from the snare of the law. For example, the offense of fraud in civil law is a criminal matter according to Article 372 in conjunction with Article 378 of the Criminal Code [Indonesia]. However, the violations referred to in Article 372 are not necessarily categorized as criminal acts according to the laws of other countries. The Indonesian Criminal Code would imply that the crime could also be an "act against the law" within the scope of civil law. ${ }^{21}$ The implementation of Article 372 was carried out in the case of disclosure of the Sjamsul Nursalim who fled to Singapore - the common law country. Here, an important question may arise. Are the recipients of BLBI bonds, such as Sjamsul Nursalim who allegedly fled to Singapore, perceived as criminals according to Singapore law especially just because they do not pay the BLBI bond obligations? Although, according to the Indonesian legal system, the fugitive is considered a criminal because $\mathrm{s} /$ he has been determined by the Corruption Eradication Commission as a suspect, the Singapore law states that "defaulting on debt" falls within the scope of "civil matters" according to the common law system. ${ }^{22}$ Such

18 T. Bingham, The Rule of Law 3 (2011).

19 G. Stessens, Money Laundering, A New International Law Enforcement 5 (2002).

20 M. Joutsen, International Cooperation against Transnational Organized Crime: Extradition and Mutual Legal Assistance in Criminal Matters, 119th International Training Course Visiting Experts' Papers 364-93 (2002), available at file:///C:/Users/user/AppData/Local/Microsoft/Windows/INetCache/IE/7VJQZEFJ/No59_28VE_Joutsen2.pdf.

21 R. Surachman, Indonesia, "ne bis in idem," or "double jeopardy" in Indonesia, 73(3) Revue Internationale de DroIt PÉNAL 1009-16 (2002).

22 See, e.g., Civil Law Act ch. 43, available at https://sso.agc.gov.sg/Act/CLA1909. 
differences in interpretation can have implications for the difference in the concept of "dual criminality" between Indonesia and Singapore which would make it difficult for fugitives to be extradited to Indonesia.

\section{Difference in Norms of Money Laundering Law in the ASEAN}

The ASEAN member countries have agreed that money laundering is a transnational crime which should be dealt collectively as affirmed in the 1997 ASEAN Declaration on Transnational Crime. ${ }^{23}$ At the level of implementation, each ASEAN member country has a different policy of criminalizing money laundering. This difference is related to not only the non-uniformity of the predicate crime/offense problem, but also the inequality of rules regarding money laundering and the minimum amount of assets subject to punishment. In Indonesian law, for example, predicate crime - the offense that originates from dirty money - is only covering as many as 25 criminal acts as mentioned in Law No. 8 of 2010 concerning the Prevention of Money Laundering. ${ }^{24}$ Conversely, Malaysia stipulates 119 criminal acts which are considered as "serious crimes"; The Philippines sets 114 unlawful activities; and Myanmar has 10 flexible acts. This means that the act of money laundering in one ASEAN country is not necessarily a similar crime in another ASEAN country.

Regarding the amount of washed money, each ASEAN country is different. For example, Indonesia sets a limit on the source of money which is seen as money laundering to 500 million rupiah, ${ }^{25}$ whereas the Philippines and Malaysia do not set such limit. Meanwhile, the limit in Myanmar is determined by the Central Control Board. ${ }^{26}$ Likewise, the subject of money laundering actors is not the same. Indonesia, for example, sets 'people' and 'corporations' as money laundering subjects, whereas Myanmar refers to only "people. ${ }^{27}$ This shows that the "predicate offenses" is limited

23 ASEAN Declaration on Transnational Crime Manila, 20 December 1997, available at https://asean.org/?static post=asean-declaration-on-transnational-crime-manila-20-december-1997.

24 B. Arief, Series of Scientific Works on Criminal Law [Kapita Selekta Hukum Pidana] 56 (2013).

25 See Property, The Money Laundering Washing Model for Narcotics Criminal Actions [Properti, Modus Pencucian Uang Hasil Tindak Pidana Narkotika], available at http://www.ppatk.go.id/siaran_pers/read/961/properti-moduspencucian-uang-hasil-tindak-pidana-narkotika.html.

26 Myanmmar Financial Intelligence Unit, The Anti-Money Laundering Central Board, available at https://mfiu.gov.mm/ anti-money-laundering-central-board.

27 Le Nguyen, supra note 10, at 383-95. 
and not always the same in all ASEAN member countries. This difference includes the limits on the source of money which is considered as money laundering, the subject of, and effective punishment against money laundering in each ASEAN country. These differences may hamper cross-national law enforcement cooperation, especially against combating money laundering as a transnational crime.

Considering the substantial regulatory system and the implementing regulations of money laundering in the ASEAN, the essential agenda is the aspects of the common vision of cross-enforcement law. An agreement is necessary between members with different legal systems to prevent the escape of perpetrators of cross-border money crimes. In other words, the same language for this transnational crime should be adopted by all ASEAN member countries together, even though, at the level of the implementation, each ASEAN member country has technically different implementing regulations. The most important thing is a shared vision among the ASEAN member countries to carry out cross-jurisdictional law enforcement especially against money laundering actors. MLAT 2004 is triggering the judicial cooperation in criminal matters in the ASEAN, especially regarding fugitives across countries.

\section{Free Movement of Judgments: Are There Conceptual Similarities with the ASEAN Single Market?}

Whether the "Free Movement of Judgments" in the criminal field can realistically be implemented in the ASEAN with diverse socio-cultural and low levels of community cohesion? To answer this question, it is worth looking at the historical experience of the ASEAN for building common political and economic framework. The ASEAN countries have diverse historical, social and cultural background. In practice, however, they are properly cooperating with each other especially in the economic field. A good example is the ASEAN single market through the implementation of the ASEAN Economic Community ("AEC"). AEC has been realized and running well for years. Freedom of business and investment, free movement of skilled people, and free movement of goods and services so far can be well implemented. ${ }^{28}$ Actually, each ASEAN member country has different historical roots. Every ASEAN member country has been colonized except for Thailand which is often considered a "balancing 
power" in the ASEAN. ${ }^{29}$ The Cold War also had grave influence on the political and military conflicts between the ASEAN countries such as Laos, Cambodia, and Vietnam, especially along their national borders. ${ }^{30}$ These environments as a whole led the peoples in this region to set up an organization - the ASEAN - to create stability. ${ }^{31}$ The ASEAN is thus trying to fulfil the justice and the rule of law under the UN Charter. $^{32}$

The ASEAN integration can be seen from the statement "to help in terms of common interests in the economic, social, cultural, scientific and administrative fields" as stated in Objective No. 3 of the ASEAN Charter to "create a single market.",33 The ASEAN's experience in diplomatically resolving political tensions and border disputes, is expected to realize the "Free Movement of Judgments" in the area of cross-border money laundering. ${ }^{34}$

The political commitment to realize the "Free Movement of Judgments" is based on "sovereign liberalization" among the ASEAN countries. As Takao Suami mentioned, in general, East Asian countries including the ASEAN members would like to defend their national sovereignty strongly and oppose any efforts to loosen it. ${ }^{35}$ According to the doctrine of non-interference of the Association, the "Free Movement of Judgments" cannot be easily enforced. Nonetheless, as long as each member is politically committed to realizing this concept, it will be materialized with economic integration in the ASEAN.

Articles 22, 23, 51, and 52 of Law [Indonesia] No. 1 of 2006 concerning Reciprocal Assistance in Criminal Matters shows embryo of the "Free Movement of Judgments" in the ASEAN. In particular, Article 22 provides: "Based on a court decision that has obtained permanent legal force, the Attorney General can submit an application to the Minister to submit a request for assistance to the Requested State to follow up on the court's decision in question in the Requested State." Article 23 states: "The court's

29 D. Bowden, N. Hicks, \& M. Shippen, Southeast Asia: A Region Revealed 35 (2013).

30 J. Öjendal, South East Asia at a Constant Crossroads: An Ambiguous New Region?, in Regionalization IN A Globalizing World: A Comparative Perspective on Forms, Actors and Processes, Chicago 201 (M.Schulz, F. Söderbaum \& J. Öjendal eds., 2001).

31 M. Schulz, F. Söderbaum, \& J. Öjendal, Regionalization in A Globalizing World: A Comparative Perspective on Forms, ACTORs, AND Processes 3 (2001).

32 ASEAN Charter art. 1.

33 Id. art. 1(5). See S. Chirathivat, \& C. Pachusanond ASEAN Prospects for Regional Integration and the Implications for the ASEAN Legislative and Institutional Framework, 16(1) ASEAN ECON. Bull. $28-51$ (1999).

34 D. Rahmah, \& T. Handayani, ASEAN Regional Arbitration Board: An Alternative Dispute Resolution in the ASEAN Region within the Framework of the ASEAN Economic Community, 8(3) J. L. \& JusT. 1-12 (2019).

35 T. Suami, Regional integration in East Asia and its legalization: Can law contribute to the progress of integration in East Asia?, in Nakamura (ed.), supra note 14, at 195-216. 
decision as referred to in Article 22 can be in the form of seizure of confiscated goods, criminal fines, or payment of compensation money."

Both provisions show that the decision of the Indonesian court can be followed up in the Requested State. Meanwhile, the requests for implementing foreign decisions in Indonesia are regulated in Articles 51, 52, and 53 of Law No. 1 of 2006, which state that requests for implementing foreign court decisions are submitted to the Minister through the Attorney General who later requests the determination of the court. However, requests for the implementation of foreign court decisions referred to in Articles 51-54 of Law No. 1 of 2006 only cover or involve the confiscation and seizure of assets, imposition of a fine, or payment of replacement money.

In this regard, the recognition and implementation of foreign decisions here would be only limited to the aspect of property and does not include the aspect of offender. In fact, the implementation of the court's ruling on fugitives who fled to foreign countries is crucial to law enforcement. Also, it can help the prosecutor to find guilty, try them, and confiscate the assets from crime in a valid manner. This is a strategic location of applying the "Free Movement of Judgments" against money laundering fugitives wherever located.

\section{Can the Free Movement of Judgments be Implemented in the ASEAN?: Reflecting on Criminal Matters in the EU}

In order to find a solution to implement the Free Movement of Judgments in criminal matters in the ASEAN, it is necessary to compare the historical experience of the formation of the European Union ("EU") and that of the ASEAN. The EU and the ASEAN member States share common factors in spite of their diverse and multicultural bases. However, the ASEAN would have more difficulties in realizing the "Free Movement of Judgments" than in the EU.

Historically, the development of a single market in European countries began with the formation of the European Economic Community in 1957. It was proven that the formation of economic integration through a single market was able to unite Europe countries as a single body. The so-called "Europeanization of Europe" was intended to increase economic and political integration in Europe. ${ }^{36}$ The economic 
integration of European countries is also followed by integration in the field of law enforcement across jurisdictions through the application of a supranational legal system. ${ }^{37}$ Today, the EU with 25 member countries has a very efficient mechanism in economic, political, and legal operation.

Regarding money laundering, the EU has signed many international treaties on criminal matters. The most important are the European Convention on Extradition 1957 and the European Convention on MLA in Criminal Matters 1959. Later, the European Council asked the European Committee in charge of criminal matters to take the necessary measures to eradicate money laundering in 1987. The European Council then formed the Expert Committee which formulated various aspects of money laundering, so that, in 1990, the Committee of Experts succeeded in delivering the Convention on Money Laundering, Searching, Freezing, and Confiscation of Asset Crimes. $^{38}$

Cooperation in the field of criminal matters in the EU is based on various reciprocal agreements, such as the Convention on Mutual Assistance in Criminal Matters between the EU Member States 2000. Recently, they use video conferencing or other telecommunications equipment as a means of proof. Law enforcement officials can directly liaise with their counterparts in the EU to request information regarding financial transactions and account suspensions. In order to obtain the various evidences, a very flexible manner should be adopted as long as it does not conflict with the legal principles of other EU member states. ${ }^{39}$

A case in the jurisdiction of other EU member states can be investigated based on the European Investigation Order 2014. This directive applies the principle of mutual recognition in the case of MLA requests while prioritizing human rights protection. Requests within the scope of this directive are treated at the same level like the handling of domestic cases from the country concerned. Also, the requests for action to conduct investigations in other countries are treated flexibly and stipulated within a limited time. ${ }^{40}$

Regarding the inter-court cooperation within the EU on the arrest warrant for perpetrators of crimes in the Union, the European Arrest Warrant provides the procedures for surrendering suspects across jurisdictions. It simplifies the

37 T. Nakamura, East Asian Regionalism from A Legal Perspective: Current Features and A Vision for the Future 3 (2009).

38 C. Howard, Butterworths Money Laundering Law 15 (1999).

39 S. Peers, Mutual Recognition and Criminal Law in the European Union: Has the Council Got It Wrong?, 41 Common Mкт. L. Rev. 5-36 (2004).

40 Treaty on Mutual Legal Assistance in Criminal Matters, available at http://agreement.asean.org/media/download/ 20160901074559.pdf. 
prosecution, executing sentences, or arrest detention orders. A court order to arrest a suspect in the territory of an EU member state applies to all members of the Union. ${ }^{41}$ This EU Detention Order came into force in 2004, which was intended as a response to convoluted extradition procedures among the EU members. Cooperation in the field of criminal law among the EU countries might have progressed well, so that such a model can later be adopted in the ASEAN.

\section{Free Movement of Judgments and Implementation of Foreign Decisions in the Civil Case under the 1958 New York Convention}

In the civil cases, the recognition and implementation of foreign decisions have been recognized and implemented globally, especially regarding foreign arbitral awards based on the 1958 New York Convention on Recognitions and Enforcement of Foreign Arbitral Awards (hereinafter New York Convention). In civil and commercial cases, a foreign court's ruling is not recognized only if the ruling is deemed contrary to the public policy of the requested state or "irreconcilable judgment." Within the EU and in the international context, however, recognition and implementation of court decisions in the civil and commercial cases are confirmed in the 2015 Brussels 1 Recast. $^{42}$

Recognition and implementation of foreign decisions, especially regarding arbitration decisions in Indonesia, are no longer a point at issue. In fact, Law No. 30 of 1999 concerning Arbitration and Alternative Dispute Resolution states that foreign or international decisions are carried out in Indonesia with regard to the public interest and Indonesian law. Recognition and implementation of foreign arbitral awards in Indonesia are possible following the ratification of the New York Convention through Presidential Decree No. 34 of 1981. The implementation of foreign arbitration awards in Indonesia was later confirmed by the Supreme Court Regulation No. 1 of 1990 concerning procedures for submission of a request for foreign arbitration in Indonesia.

41 S. Leaf, Mutual recognition in European judicial cooperation: A step too far too soon? Case study-the European arrest warrant, 10 EuR. L. J. 200-17 (2004).

42 P. Beaumont, \& L. Walker, Recognition and Enforcement of Judgments in Civil and Commercial Matters in the Brussels I Recast and Some Lessons from It and the recent Hague Conventions for The Hague Judgments Project, $11 \mathrm{~J}$. Priv. InT'L L. 31-63 (2015). 
Accordingly, the implementation of foreign court decisions in civil law cases across countries including Indonesia would be no longer a point of contention at this time. The "Free Movement of Judgments" in the ASEAN is expected to be adopted more strongly by the mutual cooperation in criminal, civil and commercial cases between Indonesia and Thailand as formulated in the Agreement on Judicial Cooperation between Indonesia and Thailand 1978. Thanks to the judicial cooperation, the court decisions in the civil and criminal cases can be recognized and implemented in both jurisdictions reciprocally. For example, inter-court cooperation allows foreign judgments to be recognized and implemented in a reciprocal way between Indonesia and Thailand. This model may be applied in the ASEAN as a whole. $^{43}$

\section{Conclusion}

The enforcement against fugitive money laundering cases fleeing to other countries is a serious legal and political issue in the ASEAN. This problem is mainly due to disharmonies between countries. Nonetheless, until now there is not a universal legal framework to solve this problem. Without extradition treaty, the court decision of the country of origin of money laundering cannot be enforced by the requested state. This in turn caused harm to the ASEAN community's sense of justice because the perpetrators were free without punishment. Therefore, MLAT 2004 should be used as an alternative, considering that this instrument can also be used against perpetrators. However, MLAT 2004 is apparently not easy to implement and rarely used even though it is still valid as a binding rule among the ASEAN countries. In this regard, the "Free Movement of Judgments" in the criminal field can be applied as a comprehensive solution because it is not constrained by the presence or absence of legal instruments, such as extradition treaty. This concept requires the cooperation between judicial bodies in the ASEAN. For legal integration in the ASEAN, the domestic court decisions of each member country against fugitives across countries should be recognized and implemented in the jurisdictions of other ASEAN member countries. The perpetrators will be then punished in the end.

In terms of legal certainty and effectiveness, MLAT 2004 can be used as an embryo for the legal integration of the ASEAN. For this purpose, the political commitments

43 S. Guatama, Recognition and Enforcement of Foreign Judgments and Arbitral Awards in the ASEAN Region, 32 Malaya L. Rev. 171 (1990). 
of the ASEAN leaders need to be followed. In the crime against cross-border money laundering, the 1997 Bangkok Declaration can be understood as a declaration of "Free Movement of Judgments" in the ASEAN. In this course, the ASEAN judiciary bodies should adopt the regulation for the implementation of court decisions against transnational fugitives in the ASEAN. Finally, each member country's domestic regulations should be comprehensively reformed for cross-country law enforcement under bilateral, regional, and international agreements. This grand scheme can be realized within the scope of governmental authority, law enforcement bodies and the authority of the judiciary body. 